\title{
Exhibiting the Austro-Hungarian Empire: The Austrian Museum for Folk Culture in Vienna, 1895-1925
}

\author{
*Julie Thorpe
}

\begin{abstract}
TheAustrian Museum for Folk Culture (Österreichisches Museum für Volkskunde) was established in 1895 in Vienna, the capital of the Austro-Hungarian Empire. ${ }^{1}$ Initially founded as 'monument of a state of nations [Völkerstaat]' it acted on and facilitated larger imperial projects of statecraft, war and international diplomacy that spanned the Empire and its displacement in the interwar period (Schmidt 1960: 29). While much of the Museum's collection was acquired in the years before the Empire's collapse in 1918, I argue that it was only in the Empire's afterlife that the Museum was able to perform its memory work for an entombed 'state of nations'. The Museum projected this site of imperial memory initially onto a post-imperial pan-European map and then, following the rise of German nationalism in Germany and Austria, onto a pan-German vision of empire and nationhood.
\end{abstract}

Keywords: Museums; collections;Austro-Hungarian empire; folk culture; international diplomacy

\section{The 'bones' of Austrian Volkskunde}

The prophetic vision of an ethnographic institution, according to a visitor to Stockholm's Nordic Museum in 1888, was to breathe life into inanimate objects:

The visual objects of a museum resemble the scattered bones on the battlefield of Ezekiel's vision. Pour a living, coherent idea into these soulless, often anonymous objects; sort them, order them, group them around their centres [and] the scattered bones will arrange themselves into figures; ethnographic objects in their unsurveyable mass will gather themselves into types, and the visitor will leave the collection with a total impression of a people now living and breathing in the provinces, in the fatherland, in the Scandinavian North (Sandberg 1995: 320).

The rapid urbanization that trebled and quadrupled the populations of Scandinavian cities in the last quarter of the nineteenth century lent urgency to the task of reanimating the 'absent folk body' that had been lost in the process of industrialization and emigration abroad (Sandberg 1995: 324-5). But the battle for lost bodies and objects was also being staged in the still largely agrarian economy of the Austro-Hungarian Empire. ${ }^{2}$ Here the battle was pitched between those who sought to claim bodies and objects for national projects and institutions, on the one hand, and those who claimed them for the empire (Zahra 2008). Both sides framed their politics in modern terms of governing diversity by sorting, ordering and grouping people and things while also educating 'spectator-patriots' in an age of mass politics (Sandberg 1995: 333).

Like its Scandinavian counterpart, the Austrian Museum for Folk Culture owed its origins to the international exhibitions of the nineteenth century (Sandberg 1995: 320). The creation of the Museum could even be described as a coming of age story for its founding director, Michael Haberlandt (1860-1940), who visited the 1873 Exhibition in Vienna as a 13-year-old boy. Later he embarked on a career in museum administration in the ethnographic collection 
of the Museum of Natural History, where he first began to sketch his ideas for an Austrian ethnographic institution with his colleague Wilhelm Hein, forming the Association for Austrian Folk Culture (Verein für österreichische Volkskunde) in 1894. The following year the Museum for Austrian Folk Culture was established with Haberlandt at the helm. Haberlandt's ideas for an institution for Austrian Volkskunde departed from the national idea of a museum in Germany and, to a lesser extent, in Scandinavian countries. But he also resisted pressure at home from German-nationalist groups to turn the Museum into an institution for German culture in the Empire. It was not only German-speakers who saw ethnography as a vehicle for nationalism in the Empire. In 1895, the same year the museum opened in Vienna, the first 'Czechoslovak' Ethnographic Exhibition was held in Prague in 1895 and led to the creation of a Czechoslovak Ethnographic Museum in 1896 (Schmidt 1960: 19-28, 41).

Distancing himself from nationalist projects, Haberlandt saw his museum as the heir of nineteenth-century ethnographic work documenting 'the lands and peoples' of the AustroHungarian empire. Emblematic of this ethnographic tradition and the empire's financial and political investment in it was the 24-volume encyclopedia, Die Österreichisch-ungarische Monarchie in Wort und Bild (The Austro-Hungarian Monarchy in Word and Picture), commissioned by the crown prince Rudolf and published in both German and Hungarian editions between 1885 and 1902. Prior to his suicide in 1889, Rudolf had dedicated his work to Austrian ethnography and, in 1899, Haberlandt wrote to offer his condolences to Emperor Franz Josef and to assure him that the 'establishment of an imperial museum for Austrian ethnography [would be] the lasting legacy of this monumental work of literature on the eve of its completion' (Beitl 1998: 13).

From its beginning, the collections of the Museum were acquired across the Empire through donations of private collections of members of the Verein and through Haberlandt's own extensive travels and personal networks in the Empire. (He was also married to a Croatian woman from Dalmatia). A collection of Moravian embroidery was one of the first acquisitions in 1896. Notable, too, was the donation of illustrations by the Viennese artist, Hans Ludwig Fischer, from his travels through the Dalmatian and Istrian crown lands. The Museum also acquired a private collection of nativity scenes, devotional images and holy cards from Bohemia with Czech prayers printed on them (Schmidt 1960: 23-5, 33-7). The Museum's displays followed the traditional ethnographic approach of presenting objects without text, except for those objects that were themselves text, like the holy cards. The approach in Vienna differed from Prague, where the Czech Ethnographic Museum displayed relief cards, showing how many Czechs and Slovaks lived in each town or village as part of a broader strategy of counting and claiming nationally indifferent populations for the nation (Schmidt 1960: 47; Zahra 2008).

Along with the rise of the popular and political press that socialized urban newcomers into an ocular culture across Europe's growing modern metropoles, the growing taste for folk art belonged to another modern movement that attracted a broad church, from German Expressionist painters to alpine associations promoting Heimat tourism and local artifacts (Fritzsche 2002). The 'Blue Rider' circle of artists in Munich identified with folk art through its leading proponents, Franz Marc and Wassilij Kandinsky. The English art periodical, Studio, under the editorship of Charles Holme, published a series on 'Peasant Art' in Europe. The Studio volume on 'Peasant Art in Austria and Hungary' was published in 1911 and included illustrations from the Austrian Museum for Folk Culture, with a contribution from Haberlandt. At the same time, Haberlandt was trying to promote his own journals on folk art, publishing the first of two volumes of Österreichische Volkskunst in 1910 and another periodical, Werke der Volkskunst, appearing in 1911 (Schmidt 1960: 54).

Not all modern artists embraced folk art, however. Secession artists in Vienna distanced themselves from Volkskunst and, in Prague, Czech artists rejected the folk motifs of Alphonse Mucha, and courted the French sculptor Auguste Rodin and the Norwegian painter Edvard Munch instead (Giustino 2010). Recent work on 'the exhibitionary complex' in East Central Europe has shown how cultural forms and practices developed under the double gaze of the international (Western) spectator and the imperial centre, during the late nineteenth and early twentieth centuries (Neuberger 2010a; Bennett 1995). As 'cultural bureaucrats' in the region held up a mirror to themselves and international audiences with a sense both of humour and shame, invisibility and visibility, and anxieties about concepts of 'West' and 'East', they were also confronting tensions at home between tradition and progress (Neuberger 2010b: 569; 
Bennett 2004: 28). ${ }^{3}$ The place of folk heritage in modern culture was as much a reflection of those tensions as it was also intended to attract the foreign gaze (Giustino 2010: 593-4). For Haberlandt and his cultural mission of 'a state of nations', the role of Volkskunst or Volkskunde was primarily an imperial one, although he was prepared to seek patrons abroad to build his museum's reputation and collections. The Museum strove to embody the Empire's 'lands and peoples' as the Empire itself became displaced by nationalism, war and internationalism in the twentieth century.

\section{The 'lands and peoples' of the empire}

Peter Fritzsche has described the relationship between traumatic memory and the assembly of 'debris' from the 'lost lives' of the pre-Holocaust generation of the 1930s in the fiction of German writer, W.G. Sebald, 'just as the collectors of the nineteenth century assembled their botanical specimens, architectural drawings, and encyclopedia articles' (Fritzsche 2006: 291). We can also see the assemblages of the 'lands and peoples' of the Austro-Hungarian Empire as an exercise in recovering and 'freezing' the imperial past in space and time, in the midst of the Empire's collapse and displacement from the map of Europe in 1918. The folk museum, then, can be seen not only as the progeny of pioneering ethnographers and the 'exhibitionary complex' of late-nineteenth-century empire, but also, as Mark Sandberg has argued, as the birthplace of modern cinema, which took up the project of traumatic memory using the same assemblages of objects and text and added a third - sound - to create a series of dynamic encounters with the recent past (Sandberg 1995; Hirsch 2004).

In this section I tour two 'lands' of the Empire - Galicia and Bosnia-Herzegovina - to sketch briefly the connections between museum practices, ethnography and empire in the years before 1918, and show how these connections inscribed both imperial and national memories into international theatres of war and peace. I begin with the 1894 Galician Provincial Exhibition in Lemberg (L'viv) before turning to Bosnia-Herzegovina, which was first exhibited on the world stage as part of the Austro-Hungarian display at the Paris International Exposition in 1900. Occupied by Austria-Hungary since 1878 and annexed in 1908, Bosnia-Herzegovina became the first theatre of the First World War in 1914. The War set the stage for another ethnographic exhibition in 1915 showcasing the Empire's displaced people and objects, and enabling Haberlandt to acquire new collections for the Museum. The imperial tour ended in Vienna after the War, where the Museum's efforts to memorialize the lost 'lands and peoples' of the Empire belonged to a new international era of European cultural diplomacy.

\section{The 1894 Galician Provincial Exhibition}

The organizers of the 1894 Galician Exhibition modeled their displays on the 1873 World Fair, so Haberlandt was not the only one to forge a career out of the Vienna exhibition (Prokopovych 2008: 271). As with the 1895 Czechos/ovak Exhibition, the Galician Exhibition gave impetus to the founding of a permanent ethnographic museum in Lemberg, albeit one that was badged in provincial rather than overtly national terms in contrast to its counterpart in Prague (Grieshofer 1998: 37-8). The visit of Emperor Franz Josef to the Exhibition was also part of an imperial itinerary intended to promote patriotism in the provinces in the lead up to the Emperor's jubilee celebrations in 1898 (Unowsky 2005). For ethnographers visiting the Exhibition, however, the attraction was not the Emperor and the pomp surrounding his visit, but rather the opportunity to collect objects and photographs to take back for the Museum for Folk Culture that was about to open in Vienna. The Museum's first purchase was a collection of photographs taken at the 1894 Exhibition depicting ethnographic representations of Galician peasant life, some of which were subsequently published four years later in the fourteenth volume of the crown prince's work on Galicia (Grieshofer 1998: 35-7).

The Museum's journal, which began annual circulation in 1895, published regular updates on new acquisitions, names of donors as well as an 'ethnographic chronicle from Austria' with contributions from staff, donors and friends of the Museum (Schmidt 1960: 49). For the journal's inaugural volume, a schoolteacher from Trzebinia in Galicia, Adele Pfleger, wrote up her impressions of her visit to the 1894 Galician Exhibition. Her entry resembled the 1888 
guidebook to the Nordic Museum in Stockholm, guiding the reader through the ethnographic pavilion and the 'international Galician village' with its domed church, bell tower, standing crucifixes and an old Ruthenian man playing a hand organ. There were more 'live' models in the ethnographic pavilion - girls in traditional dress decorating their hair with flowers and bands of embroidered cloth while stitching their blouses with woolen thread - alongside mannequins wearing peasant costume and middle-class gold and silver bodices and caps. Other exhibits of antiquarian objects, folk literature, Easter and wedding cakes, musical instruments, baskets, ceramics and horse harnesses took the visitor from pre-history to living history, showcasing the people's past and present material, social and spiritual subsistence (Pfleger 1895). It was this 'mimetic' or 'functionalist' approach to recreating domestic and village life in tableaux using both live and plaster models that conjured up folk bodies in journalists' and tourists' accounts of ethnographic exhibitions and museums. Unwittingly, perhaps, the organizers of these displays created, as Sandberg writes, 'two competing collections - one purposeful, complete and selfsufficient, and the other (consisting of the leftovers) inescapably miscellaneous' (Sandberg 1995: 325-7, 346). While exhibited people stayed frozen in time and space in the imaginations of those who encountered them in a visit, guidebook or newspaper, the 'leftovers' could be sold, exchanged and dispatched to collections elsewhere in the Empire.

In 1904, ten years after the Galician Exhibition, the Museum conducted its first expedition to the eastern Carpathian region and acquired on this trip a collection of glass pearl necklaces, hand-painted Easter eggs, woven carpets, sheep fur vests and embroidered linen used for festive clothing and for decorating bed and table cloths. Lightweight for ease of transport back to Vienna, the objects were often family heirlooms and rarely sold to ethnographers, but were donated by individuals known to Haberlandt and his associates (Zeitschrift für Österreichische Volkskunde 1925: 49; Plöckinger 1998: 59-60, 70-3). ${ }^{4}$

Michael Haberlandt's son, Arthur (1889-1964), took over much of the collecting work from his father and he reported in 1911, after a recent trip back to Lemberg, that success could be gauged not by the numbers of things purchased or donated, but in the expanding network of contacts with local ethnographic museums and associations and private collections. The personal relationship with a director of an archdiocesan museum, for example, with its rich collection of Ruthenian sacral and folk art was of greater value to the museum's growing reputation in the empire than more donations of 'leftover' necklaces (Haberlandt 1911). Such a two-pronged strategy of collecting and networking required astuteness in cultural diplomacy, political expediency - as we have already seen in Haberlandt's petition to the Emperor - and, once war broke out in 1914, the art of military strategy.

\section{Exhibiting Bosnia and Herzegovina}

Even before the Austrian archduke's assassination in Sarajevo in June 1914, the AustroHungarian Empire had put Bosnia-Herzegovina on the world stage in the 1900 Paris Exhibition. In Vienna, efforts had also been underway at home to capture the imagination of the imperial capital toward Balkan 'folk' culture. An exhibition on Bosnia-Herzegovina was held in 1891 in Vienna's Arts and Crafts Museum, followed by an Adria Exhibition in 1913, under the patronage of local aristocratic women who also produced an illustrated edition of 'Dalmatia and its Folk Art' in 1910 (Schmidt 1960: 63). After Austria-Hungary invaded Serbia in 1914, Bosnia-Herzegovina became a theatre of war between Serbian and Austro-Hungarian troops, but this did not prevent the Museum from undertaking a Balkan expedition in 1915-16, under the protectorate of the War Ministry, to collect material. Oberleutnant Ernst Neweklowsky led the expedition along with Arthur Haberlandt, who had been conscripted into the army in 1915. The group brought back clothing, artwork, photographs and other objects from Montenegro, Serbia and Albania that went on display in the Oriental section of the War Ministry's Exhibition of Folk Art of the occupied Balkan territories in January 1918 at the University of Vienna. After the Exhibition the War Ministry donated the objects to the Museum's collection (Schmidt 1960: 64; Marchetti 2010).

The War Ministry's Exhibition of Folk Art was not the only wartime exhibition to showcase the 'lands and peoples' of the empire. Between 1914 and 1918, more than 50 separate exhibitions appeared in Vienna. The largest and longest running of these was the 
Vienna War Exhibition, which opened on the grounds of the city's famous Prater Park in July 1916 , and was seen by more than one million people by the end of its run a year later. Other exhibitions, far more modest in scale, were staged in galleries or public buildings. Yet the minor shows still made the columns of the Viennese press, if only to report the glittering openings attended by Habsburg royalty. Victims of the War, notably the war wounded, featured in many of these exhibitions. War orphans and widows were also prominent, if not directly visible, in the exhibitions of children's artwork or in the designs for war graves shown at the Vienna War Exhibition (Healy 2004: 84-121). However, a fourth group of war victims were exhibited to the Viennese public in the Kriegshilfeausstellung (War Aid Exhibition) at the end of 1915. Refugees from the Russian and Italian fronts - the Empire's homeless citizens - became the newest spectacle in a city that had become a fairground for war itself.

\section{Refugees at the 1915 War Aid Exhibition}

The 'disciplining' role of exhibitions was never greater than in an age of total war, where surveillance and denunciations became a new code of civilian conduct. But greater also was the need for finding new avenues of war entertainment to boost morale and patriotic commitment to the war effort (Neuberger 2010a: 543; Bennett 1995: 61-2). The latest medical innovations in prosthetic limbs on display at the Vienna War Exhibition, alongside soldiers playing musical instruments using their new prosthetic limbs, was a way to regulate and rehabilitate disfigured bodies while providing public information and amusement at the same time (Healy 2004: 111-6). The War Aid Exhibition was based on a similar logic of instruction and recreation. Sponsored by the Interior Ministry, the exhibition aimed to showcase the generosity of the state, public and private aid to more than a million of the empire's displaced citizens. Just as the War Ministry's Folk Art Exhibition the following year displayed the spoils of war, the Interior Ministry's War Aid Exhibition promoted the official line that unity in diversity bound together the emperor's subjects in war as in peace.

The Interior Ministry invited a press delegation to attend the opening of the Exhibition in December 1915, who in turn wrote up their impressions for their readers with mostly positive reactions to the relief work and some criticisms by the socialist press. What stands out across all the newspaper coverage is awe at the dexterity of the refugees' own handiwork that was on display alongside statistical graphs and model barracks. The Exhibition was laid out much like the 1894 exhibition in Lemberg, with a model farmhouse built and furnished by the refugees in the camps complete with hand-painted wooden cradle and bed, gold-plated icons on the wall and red geraniums in the windowsill. There were no live models, only a few mannequins, but photographs of refugees in the camps, schoolbooks with children's handwriting, and handmade dolls dressed in Polish national costume conjured up the 'absent folk bodies' of refugees in the visitor's imagination. For Baroness Lapenna, whose report of the exhibition for the conservative newspaper, Die Reichspost, read like the guidebook accounts of nineteenthcentury visitors to exhibitions and folk museums, the exhibition provided an affective encounter with the refugees whom she addressed directly in her article as 'you homeless ones' and 'you poorest children of the great fatherland' (Reichspost 16 December 1915: 1-2). Reading the German sentences of an 11-year-old Ruthenian school child in the camps brought her closer in her own imagination to the empire's homeless children, as did the displays of quilts and cushions sewn by young girls that were labelled with their names, ages and the length of their training in the camps: 'Made by 11-year old Santa Calligaris from Monfalcone after a 6-month apprenticeship', '12-year-old Maria Cavalcanti from Mori', and so on (Reichspost 16 December 1915: 1-2). The hand-made dolls could be purchased as Christmas presents with profits going back into the workshops for refugees (Wiener Bilder 19 December 1915: 10-2). Anything leftover from the Exhibition that could not be used for the war effort was boxed away for collectors to bid for.

Haberlandt had his eye on the collection very early on and had already in the course of 1915 been donating some of the museum's metal objects to the War Ministry's Metal Collection in exchange for items from the War Ministry's Art Section (Zeitschrift für Österreichische Volkskunde 1915-6: 136). ${ }^{5}$ After visiting the War Aid Exhibition, Haberlandt began lobbying 
for the objects to become part of the museum's permanent collection:

During the occupation of East Galicia the brutal efforts of the Russians to halt and wipe out the national forces of the Ruthenian population, have utterly destroyed every last piece of evidence of folk art work in the museums, private collections and farmhouses. It is imperative now to rescue the rural folk art ornamental treasures of Eastern Galicia out of the faithful memories of the agricultural refugees, while the girls and women from the individual villages remain in the refugee camps, to create the sample patterns of the traditional ornaments familiar to them, by which now a wholly unique collection... of ornamental treasures from eastern and central Galicia has been brought into fruition. [...] This act will remain for all time a testimony of distinction for the cultural and ethnographic work of the state administration (Haberlandt 1915-6: 127-8).

In 1921 the Interior Ministry sold its collection of refugee artefacts to Haberlandt's museum for a sum of just over 3000 crowns. ${ }^{6}$ The refugees had become not lost bodies of the Empire, but lost hands that could stitch together the Empire's cultural heritage with fabric, needle and thread. Disembodied and displaced from families, homes and communities, refugee hands became the property of cultural ownership in the empire and the site of contested memories in the post-imperial reconstruction of East Central Europe.

\section{After Empire}

By war's end the Museum had a collection of over 40,000 objects and a new home in Vienna's eighth district. In a lecture in 1917, reprinted in the museum's journal, Michael Haberlandt rejected any notion that the museum was a tomb for the Emperor's lost lands and people, describing it instead as a garden in which the Empire's nationalities could be planted and nourished. The Museum, Haberlandt said, 'is not a silent cemetery, after all, where the old fatherly ways and skills are laid to rest in a coffin, but rather a nursery for seedlings and a garden of new strength and blossoming of nations' (Zeitschrift für Österreichische Volkskunde 1917: 5).

The vital life force that the Museum purported to contain was defined still in terms of a state of nations, but one in which the state was no longer the old Austro-Hungarian Empire but the Empire of Europe. Even the Museum's pre-fix 'Austrian' was replaced with 'Viennese', referencing the seat and throne of the former Holy Roman Empire. It was no coincidence that the Museum's new premises were housed in the eighteenth-century summer palace of Count Friedrich Karl von Schönborn (1674-1746), a former bishop and deputy chancellor of the Holy Roman Empire. References to the museum after 1918 stressed the European rather than imperial identity of the museum and its collections as encompassing the lands not only of the former Habsburg monarchy, but also of Germany, Switzerland, Italy, France and the former Russian Empire. In 1919, the Museum claimed its status as 'the only scientific institute in Europe with an Austrian collection at its core that at the same time has at its disposal at large a European folk culture collection of the greatest kind' (Zeitschrift für Österreichische Volkskunde 1919: 103). Opening its refurbished rooms to the public in 1920, the Museum introduced its collection as 'the largest and most important "folk art" museum in Europe' (Zeitschrift für Österreichische Volkskunde 1920-1: 16). 23 rooms of the Museum's main display on the first floor corresponded with the lands of the former monarchy grouped together by geography and history. The lands and people of 'German Austria' took up the first 16 rooms of the Museum, the next four were devoted to the Sudeten lands (Silesia, Moravia and Bohemia), and the final three to the Carpathian lands (Galicia, Bukowina and East Silesia). The Adriatic and Balkan lands were in a separate display alongside collections from Switzerland, France and Italy (Zeitschrift für Österreichische Volkskunde 1920-1: 16-28).

Under the new directorship of Arthur Haberlandt, who took over from his father in 1924, the Museum continued to navigate a European path, but one that was pursued increasingly through bilateral German relations. The Museum acquired its first Scandinavian collection from Hamburg's Museum für Völkerkunde (Schmidt 1960: 71). At the same time, it sought to build its networks with regional Austrian museums and associations in Styria and Carinthia, where German-nationalist groups and colonists from Germany were most active in promoting 
local German culture at the expense of Slovenes (Schmidt 1960: 81-2). ${ }^{7}$ It would require further space to chart these increasingly nationalist directions in ethnography and museums in post-imperial Austria. The Museum's relations with its East Central European neighbours both during and since the period of Soviet communism would require even further space. The larger point here is that as the Museum held up a mirror to the lands and peoples of the empire whose patronage and personages it had sought after since its inception, it became an effigy and, finally, an epitaph on an entombed 'state of nations'. Even if that state could be reanimated with both the racialized and ideologized blood of a new Europe of nations, the Museum continued its work of collecting, grouping, naming and reassembling the remnants of empire within the governing local and international structures that replaced it.

\section{Conclusion}

The political and cultural imperative to collect, house and exhibit drove museum policy in the late Austro-Hungarian Empire through to its collapse in 1918. As we saw in the first section of the article, Haberlandt was the life force behind the Austrian Museum of Folk Culture, and drew on all his political, economic and diplomatic skills honed during his early career as a public servant. He was a collaborator both at home and abroad, and positioned his museum and its growing collection within an imperial and international network of museum and art patrons, in peacetime and in war. My expedition through the Empire in the second section of the article followed Haberlandt's as he shifted the focus of his museum collections from Galicia to Bosnia-Herzegovina before the war and then engaged in the military art of 'anthropology in uniform' to access new spaces and objects in wartime (Scheer et al. 2010: 54).

We can also see the assemblages of Austria-Hungary's lost 'lands and peoples' as a form of remembering an irrecoverable past at a time of imperial crisis. In the words of the nineteenth-century Prussian scholar and politician, Wilhelm von Humboldt, the 'homely huts' of Austria-Hungary's peasants that were torn down by war were recreated in the imperial 'palaces' of exhibitions and museums in the metropole, though they remained foreign (and therefore lost) bodies of empire (Runia 2007). The ethnographic project of recreating peasant huts in imperial and post-imperial metropoles was thus an act of commemorating the irrecoverable bodies of empire by those who remained foreign to that past.

Received: 2 September 2013 Finally Accepted: 15 January 2015

\section{Notes}

1 I use the term Austria-Hungary or Austro-Hungarian Empire to refer to the lands of the Habsburg monarchy, which included Hungary. In 1867, a constitutional agreement with Hungary split the Empire into two constitutional halves with separate governments, but united by the monarchy, joint military and foreign affairs.

2 Vienna's population also quadrupled during the second half of the nineteenth century from 400,000 to 2 million.

3 Bennett's term 'cultural bureaucrats' denotes those agents of culture - museum directors and curators, education officers and commissioners of exhibitions -who deployed not one but several strands of culture that intersected in some spaces and times (such as international exhibitions) and diverged in others (in the contested landscape of national and imperial institutions, for example).

4 For example, a Ruthenian doctor, Iwan Franko, and a Galician schoolteacher, Ludwig Mlynek, donated one of the Museum's collections from Eastern Galicia.

5 The Museum's wartime acquisitions also included objects from Russian prisoner of war camps in Austria-Hungary. 
6 Inventarbuch des Österreichischen Museums für Volkskunde und Herkunftsakten zu ÖMV/38.398-38.942.

7 The Styrian Volkskunde Museum in Graz was founded in 1916 and the Carinthian Heimat Museum in Klagenfurt in 1926.

\section{References}

\section{Primary Sources}

Inventarbuch des Österreichischen Museums für Volkskunde und Herkunftsakten zu ÖMV/38.398-38.942.

Die Reichspost, 16 December 1915: 1-2.

Wiener Bilder, 19 December 1915: 10-2.

Zeitschrift für Österreichische Volkskunde, 1915-6, 1917, 1919, 1920-1.

\section{Secondary Sources}

Beitl, K. (1998) 'Zur Einführung', in Klaus Beitl (ed) Galizien: Ethnographische Erkundungbei den Bojken und Huzulen in den Karpaten. Begleitbuch zur Jahresausstellung 1998 des Ethnographischen Museums Schloss Kittsee (Burgenland), Vienna: Österreichisches Museumfür Volkskunde/Kittsee: Ethnographisches Museum Schloss Kittsee.

Bennett, T. (2004) Pasts Beyond Memory: Evolution, Museums, Colonialism, London: Routledge.

Bennett, T. (1995) The Birth of the Museum: History, Theory, Politics, London: Routledge.

Fritzsche, P. (2006) 'W.G. Sebald's Twentieth-Century History', in Scott Denham and Mark McCulloh (eds) W.G. Sebald: History, Memory, Trauma, 291-300, Berlin: W. de Gruyter.

(2002) 'Readers, Browsers, Strangers, Spectators: Narrative Forms and Metropolitan Encounters in Twentieth-Century Berlin', in Malcolm Gee and Tim Kirk (eds) Printed Matters: Printing, Publishing and Urban Culture in Europe in the Modern Period, 88-104, Aldershot: Ashgate.

Giustino, C. (2010) 'Rodin in Prague: Modern Art, Cultural Diplomacy and National Display', Slavic Review, 69(3) 591-619.

Grieshofer, F. (1998) 'Die Bedeutung des Ausstellungswesens für die Entwicklung der Ethnographie in Galzien und Wien', in Klaus Beitl (ed) Galizien: Ethnographische Erkundung bei den Bojken und Huzulen in den Karpaten, 19-41, Vienna: Österreichisches Museum für Volkskunde/Kittsee: Ethnographisches Museum Schloss Kittsee.

Haberlandt A. (1911) 'Galizische Ethnographie und Volkskunst', Zeitschrift für Österreichische Volkskunde, 17 83-5.

(1915-6) 'Ausstellung von Flüchtlingsarbeiten', Zeitschrift für Österreichische Volkskunde, 21-2 127-8. 
Healy, M. (2004) Vienna and the Fall of the Habsburg Empire: Total War and Everyday Life in World War I, Cambridge: Cambridge University Press.

Hirsch, J. (2004) Afterimage: Film, Trauma, and the Holocaust, Philadelphia: Temple University.

Marchetti, C. (2010) 'Austro-Hungarian Volkskunde at War: Scientists on Ethnographic Mission in World War I,' in Reinhold Johler, Christian Marchetti and Monique Scheer (eds) Doing Anthropology in Wartime and War Zones: World War I and the Cultural Sciences in Europe, 220-8, Bielefeld: Transcript.

Neuberger, M. (2010a) 'Introduction: Exhibiting Eastern Europe', Slavic Review, 69(3) 53946.

(2010b) 'Fair Encounters: Bulgaria and the "West" at International Exhibitions from Plovdiv to St Louis,' Slavic Review, 69(3) 547-70.

Österreichische Zeitschrift für Volkskunde (1925) Festschrift für Michael Haberlandt: Zum dreissigjährigen Bestand der Zeitschrift für österreichische Volkskunde, Vienna: Verein für Volkskunde.

Pfleger, A. (1895) 'Die ethnographische Abtheilung auf der Landes-Ausstellung zu Lemberg im Jahre 1894', Zeitschrift für Österreichische Volkskunde, 1 15-17.

Plöckinger, V. (1998) 'Historisch-ethnographische "Entdeckungsreise" zu den Bojken und Huzulen in Ostgalizien,' in Klaus Beitl (ed) Galizien: Ethnographische Erkundung bei den Bojken und Huzulen in den Karpaten, Vienna: Österreichisches Museum für Volkskunde/Kittsee: Ethnographisches Museum Schloss Kittsee.

Prokopovych, M. (2008) Habsburg Lemberg: Architecture, Public Space, and Politics in the Galician Capital, 1772-1914, West Lafayette: Purdue University Press.

Runia, E. (2007) 'Burying the Dead, Creating the Past', History and Theory, 46(3) 313- 25.

Sandberg, M. (1995) 'Effigy and Narrative: Looking into the Nineteenth-Century Folk Museum', in Leo Charney and Vanessa Schwartz (eds) Cinema and the Invention of Modern Life, 320-61, Berkeley: University of California Press.

Scheer, M., Marchetti, C. and Johler, R. (2010) '“A Time Like No Other”: The Impact of the Great War on European Anthropology', in Reinhold Johler, Christian

Marchetti and Monique Scheer (eds), Doing Anthropology in Wartime and War Zones: World War I and the Cultural Sciences in Europe, 9-26, Bielefeld: Transcript.

Schmidt, L. (1960) Das österreichische Museum für Volkskunde: Werden und Wesen eines Wiener Museums, Vienna: Bergland.

Unowsky, D. (2005) The Pomp and Politics of Patriotism: Imperial Celebrations in Habsburg Austria, 1848-1916, West Lafayette: Purdue University Press.

Zahra, T. (2008) Kidnapped Souls: National Indifference and the Battle for Children in the Bohemian Lands, 1900-1948, Ithaca: Cornell University Press. 
*Julie Thorpe is an Australian Research Council Postdoctoral Fellow located in the Institute for Culture and Society at the University of Western Sydney. Her work deals with social, cultural and legal concepts of citizenship; political ideologies; and religious and material culture in twentieth-century Central and Eastern Europe, with a particular focus on the place of minorities, migrants and refugees in transnational histories of the region. She also has an interest in Catholic devotional and associational life in Central Europe in the twentieth century. Her first book, Pan-Germanism and the Austrofascist State, 1933-38, was published by Manchester University Press in 2011.

Dean's Unit

University of Western Sydney

School of Humanities and Communication Arts, Parramatta EQ.1.44

Locked Bag 1797

Penrith NSW 2751

Australia

Tel: +61 (02) 96859863

Fax: +61 (02) 97726111

Email: j.thorpe@uws.edu.au 